Ethiopian Journal of Environmental Studies \& Management 8(Suppl. 2): 939 - 948, 2015.

ISSN:1998-0507

Submitted: July 18, 2015

doi: http://dx.doi.org/10.4314/ejesm.v8i2.8S

\title{
ASPECT OF GROUNDWATER QUALITY EVALUATION IN ITAPA EKITI, SOUTHWESTERN NIGERIA
}

\author{
*IGE, 0.0. ${ }^{1}$ AND KORODE, I.A. ${ }^{2}$ \\ ${ }^{1}$ Department of Geology and Mineral Sciences, University of Ilorin, Ilorin, Nigeria P.M.B \\ 1515, Ilorin, Nigeria \\ ${ }^{2}$ Department of Petroleum Engineering and Geosciences, Petroleum Training Institute, P.M.B. \\ 20, Effurun, Delta State, Nigeria
}

\begin{abstract}
Hydrochemical investigation of thirty groundwater samples from Itapa in Ekiti State was carried out between $28^{\text {th }}$ and $30^{\text {th }}$ of January, 2015. This was aimed at evaluating the composition of major ions and their origin; establish hydro-chemical facies and determining their suitability for drinking and irrigation purposes. Electrical conductivity, $p^{H}$, Total Dissolved Solids and Temperature were measured in-situ while hydrochemical analyses were carried out in the laboratory for chemical parameters. From the results, it was found that sodium and chloride are the dominant ions of the total chemical budget. The $p^{H}$ ranges from 7.5-7.9, electrical conductivity ranges from $30-900 \mu \mathrm{s} / \mathrm{cm}$. The chemical characteristics of the water revealed that the cationic concentrations is in the order of $(\mathrm{Na}+\mathrm{k})>\mathrm{Ca}^{2+}>\mathrm{Mg}^{2+}$ while anionic concentrations is in the order of $\mathrm{Cl}^{-}>\mathrm{HCO}_{3}{ }_{3}>\mathrm{SO}_{4}{ }^{-2}$. The source of the ions in the water is classified as rock weathering activity that result into three major hydrochemical facies of $\mathrm{CaNaCl}>\mathrm{CaHCO}_{3}>\mathrm{NaCl}$. Wilcox, Kelley and magnesium ratios suggested that majority of water samples are good for irrigation.
\end{abstract}

Key Words: Groundwater, Itapa, Evaluation, Ekiti, Southwestern, Nigeria

\section{Introduction}

The sources of water for any specific purpose are not as important as its suitability for the desired purpose (Ige et al., 2008). Water is the essence of life and safe drinking water is a basic human right essential to all (Versari et al., 2002). It is essential for the well-being of mankind and for sustainable development. Though, necessary for human survival, many are denied access to sufficient potable drinking water supply and sufficient water to maintain basic hygiene. Consumption of water in Ekiti metropolis has increased over the year probably, due to increase in population as a result of migration, procreation, industrialization and agricultural practices. Water is capable of dissolving minerals present in the rock below the surface and also some polluting effluents are capable of percolation into the subsurface, thereby, contaminating the potable groundwater (Asiwaju-Bello and Akande, 2004). With increasing human population, industrialization, urbanization and the consequent increase in demand for water for both domestic and industrial uses, the attendant increase in the implication of polluted water on man and the environment have been severally 
studied (Asiwaju-Bello and Akande, 2004; and Ige et al., 2008). Therefore, there is a need for thorough assessment of the quality of water available for human consumption as well as agricultural and industrial purposes.

The study area is Itapa metropolis, which is one of the towns that share boundary with the Local Government Headquarter town (Oye). It is bounded by latitudes $7^{\circ} \quad 53^{\prime} \mathrm{N}$ and $7^{\circ} \quad 54^{\prime} \mathrm{N}$ and Longitudes $5^{\circ} 18^{\prime} \mathrm{E}$ and $5^{\circ} 22^{\prime} \mathrm{E}$ covering an area of about $52 \mathrm{~km}^{2}$. It has Ilupeju, Osin and Oye as major adjourning towns (Figure 1). The town lacks adequate supply of water as there are insufficient public water supply systems. Hence, the people resort to rain water, surface and groundwater for their water demands. The climate of the study area is tropical, consisting of rain forest vegetation. The drainage is generally dendritic with hummocky and undulating topography. Annual rainfall is about $1300 \mathrm{~mm}$ and its distribution is bimodal within hydrologic year (Ayoade, 1977). The first peak occurs in June-July while the second peak occurs in September - October wet season. The two wet seasons are normally separated by a draught (August-break), while the dry season is defined by little or no rainfall between November and April (Ayoade, 1977).

\section{Materials and Methods}

A total of 30 handdug wells were sampled within the study area for physicochemical analyses between $28^{\text {th }}$ and $30^{\text {th }}$ of January, 2015 representing the dry season. All samples were collected in 2 litre preconditioned polyethylene bottles. They were initially rinsed with $10 \%$ nitric acid and followed by 3-4 time rinsing with distilled water to ensure that the sample bottles were free from any impurities. Samples collection, preservation and treatment were done according to standard methods (APHA, 1995).

At each sampling location, samples were collected into polyethylene bottles in duplicate for cation and anion analysis. Samples for cation analysis were acidified with concentrated nitric acid. Prior to this, field in-situ parameters such as $\mathrm{pH}$, temperature and electrical conductivity were measured using Multi-parameter Testr $^{\mathrm{TM}} 35$ series Meter. The samples were then preserved in a refrigerator prior to laboratory analyses. All chemical analyses were done using the Inductively Coupling Plasma Oxygen Emission Spectrometer (ICPOES) analytical method at ACTLABS Laboratory, Canada.

Hydrochemical facies and suitability for drinking purpose was determined using the Piper's trilinear diagram and Scheoller plot while suitability of the waters for irrigation was confirmed using Wilcox's diagram, Kelley's ratio. In addition, the source of ion in water was examined and classified using the Gibb's diagram.

\section{Results and Discussion \\ Physicochemical Properties}

Table 1 presents the statistical summary of chemical analyses while Figure 2 shows the variation of chemical parameters in the water of the study area. The $\mathrm{pH}$ values of water are about neutral, ranging from 7.2 to 7.7 with an average value of 7.45. The concentration of TDS ranges from 30 to $900 \mathrm{mg} / 1$ with a mean of $254.8 \mathrm{mg} / 1$. According to Fetter (1990), most of the groundwater samples collected during these periods belong to fresh water type (TDS $<1,000 \mathrm{mg} / 1)$.

The concentration of cations $\left(\mathrm{Ca}^{2+}\right.$, $\mathrm{Mg}^{2+}, \mathrm{Na}^{+}, \mathrm{K}^{+}$) ranged from 2.18 to 51.24 ; 1.05 to $15.36 ; 0.78$ to 46.80 and 0.41 to $31.98 \mathrm{mg} / 1$ with a mean of $32.10 ; 6.01$; 23.30 ; and $12.50 \mathrm{mg} / 1$ respectively. The order of abundance is $\mathrm{Na}^{+}$ 
$>\mathrm{K}^{+}>\mathrm{Ca}^{2+}>\mathrm{Mg}^{2+}$. The concentration of anions $\left(\mathrm{HCO}_{3}^{-}, \mathrm{SO}_{4}^{2-}, \mathrm{CI}^{-}, \mathrm{NO}_{3}^{-}\right)$varied from 18.0 to $180.0 ; 0.85$ to $56.10 ; 0.10$ to 90.64 and 0.14 to $11.27 \mathrm{mg} / \mathrm{l}$ with a mean of $58.3 ; 12.70 ; \quad 39.1$ and $1.0 \mathrm{mg} / \mathrm{l}$ respectively. The electrical balance and ionic difference gave average values of 0.2 and 0.7 respectively, which indicate a fairly balanced ionic concentration and potability of water samples for drinking (Appelo and Postma, 2005).

\section{Water Quality Evaluation \\ Piper and Schoeller Plots}

The evolution of hydrochemical parameters of groundwater can be understood by plotting the concentration of major cations and anions in the Piper's and Schoeller's diagrams. Figure 3 shows that $67 \%$ of the water samples analyzed fell in the field of Mixed $\mathrm{Ca}-\mathrm{Mg}-\mathrm{Cl}, 23.3 \%$ fell in $\mathrm{Ca}-\mathrm{HCO}_{3}$ and $23.0 \%$ fell in the field of $\mathrm{Na}-\mathrm{Cl}$. From the plots, it is observed that the alkaline earth $\left(\mathrm{Ca}^{2+}\right.$ and $\left.\mathrm{Mg}^{2+}\right)$ balances the alkalis $\left(\mathrm{Na}^{+}\right.$and $\left.\mathrm{K}^{+}\right)$. The general water facie distributions indicated that the examined water resources are suitable for drinking purpose.

\section{Gibbs' diagram}

The source of the dissolved ions in groundwaters can be understood by Gibbs diagram (Gibbs, 1970). It is a plot of $\left(\mathrm{Na}^{+}\right.$ $\left.+\mathrm{K}^{+}\right) /\left(\mathrm{Na}^{+}+\mathrm{K}^{+}+\mathrm{Ca}^{2+}\right)$ vs $\log$ TDS and $\mathrm{CI}^{-} /\left(\mathrm{CI}^{-}+\mathrm{HCO}_{3}^{-}\right)$vs $\log \mathrm{TDS}$. Figure 4 shows that almost all the samples fall in the rock weathering dominance area. The Gibbs' diagrams suggest that chemical weathering of the rock forming minerals is the main process which contributes to the concentration of ions in the water.

\section{Kelley ratio}

Kelley ratio is used to determine suitability of groundwater for irrigation purpose. Sodium measured against calcium and magnesium was considered by Kelley (1951) for calculating Kelley's ratio. Groundwater having Kelley ratio more than one (1) is generally considered as unfit for irrigation. Kelley ratio for water samples varies from 0.12 to 1.58 with mean of 0.64 (Table 1). According to Kelley's ratio, $93.5 \%$ of the samples were found to be suitable for irrigation whereas $6.5 \%$ were fairly suitable.

\section{Magnesium ratio}

Magnesium presence in soil and water would adversely affect their quality and render the soil unfit for cultivation (Chandu et al., 2008). Magnesium ratio of more than $50 \%$ in a body of water sample will make the water poisonous to plants (Rajmohan and Elango, 2005). Table 1 reveals that $100 \%$ of samples showed magnesium ratio far less than 50\% which confirms the suitability of the water samples for irrigation.

\section{Wilcox diagram}

Wilcox (1948) used percentage sodium and electrical conductance in evaluating the suitability of groundwater for irrigation. The results (Table 1) show that $85 \%$ of the water samples clustered in the zone of very good to good while $15 \%$ is plotted at the boundary of good to permissible (Figure 4). Therefore the water samples are good for irrigation (Wilcox, 1948).

\section{Conclusion}

The variations of the chemical parameters is in the order of $(\mathrm{Na}+\mathrm{K})>\mathrm{Ca}^{2+}>\mathrm{Mg}^{2+}$ and $\mathrm{Cl}^{-}>\mathrm{HCO}_{3}^{-}>\mathrm{SO}_{4}{ }^{-2}$ for cations and anions respectively. TDS values are generally lower than the permissible limit and the average concentration of the major ions is found to be within the WHO permissible limit, indicating passive leaching predominated by dilution effects on the water.

The Gibbs' diagrams show that the composition of water during sampling period is dominated by rock forming mineral. From Piper diagrams, hydro- 
chemical facies in the area are mixed $\mathrm{CaNaCl}>\mathrm{CaHCO}_{3}>\mathrm{NaCl}$ in the order of dominance. Results from Kelley's ratio, Magnesium ratio and Wilcox diagram are within recommendations. These signify the usefulness of the water for irrigation purpose. Further works emphasizing biological studies will be done along with hydro-chemical studies during raining season.

\section{References}

APHA (1995). Standard methods for the examination of water and wastewater. 19th edition. American Public Health Association, Washington DC. 1467.

Appelo, C.A.J. and Postma, D. (2005). Geochemistry, Groundwater and Pollution. $2^{\text {nd }}$ edtition, Balkema Publishers, Amsterland.

Asiwaju-Bello, Y.A. and Akande, O.O. (2004). Urban groundwater pollution: Case study of a Disposal sites in Lagos metropolis. Journal of Water Resources. 12: 22-26.

Ayoade, J.O. (1977). Evaporation and evapotranspiration in Nigeria. Journal of tropical geography. 44: 9-19.

Chandu, S.N., Subbarao, V. and Raviprakash, S. (2008). Suitability of groundwater for domestic and irrigational purposes in some parts of
Jhansi District, Indian. Bhu-jal News, 10: $12-18$.

Fetter, C. (1990). Applied hydrogeology. CBS Publishers and Distributor, New Delhi, India, 234p.

Gibbs, R.J. (1970). Mechanisms controlling world water chemistry. Journal of Science, 17: 1088-1090.

Ige, O.O., Bale, R.B. and Olasehinde, P.I. (2008). Physio- chemical characteristics of water sources in Imeko, Southwestern, Nigeria. Water Resources. 18: 32-36.

Kelley, W.P. (1951). Alkali soils-Their formation properties and reclamation. $3^{\text {rd }}$ edition. Reinhold Publication, New York, USA, 92p.

Rajmohan, N. and Elango, L. (2005). Nutrient chemistry of groundwater in an intensively irrigated region of Southern India. Environmental Geology. 47: 820-830.

Versari, A., Parpinello, G. P., and Galassi, S., (2002). Chemometric survey of Italian bottled mineral waters by means of their labeled pysico-chemical and chemical composition. J. Food Compos Anal, 12:251-64

Wilcox, L.V. (1948). The quality of water for irrigation use. US Department of Agriculture. Technical Bulletin of 1962, Washington, USA. 


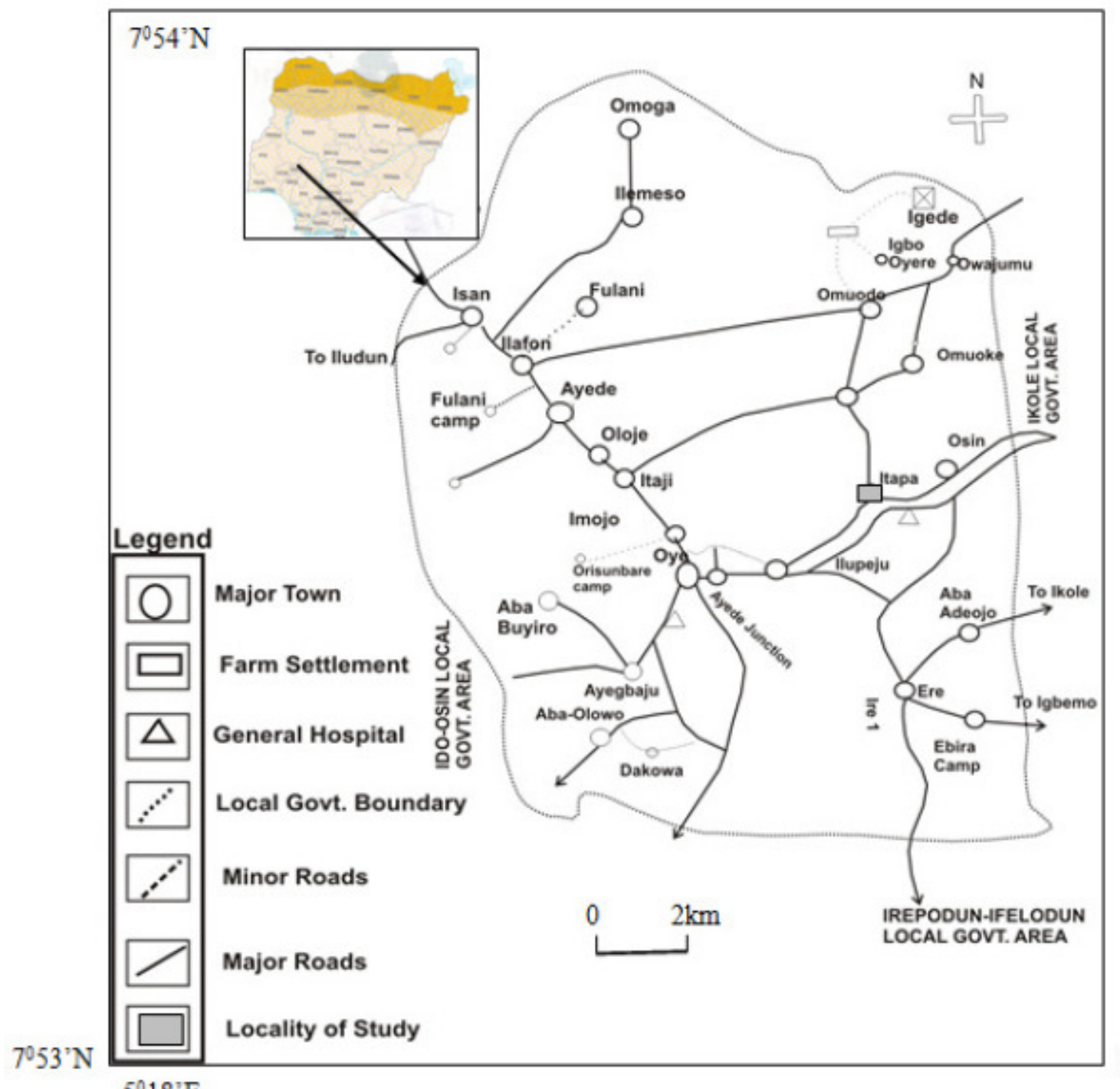

$5^{0} 18^{\prime} \mathrm{E}$

Figure 1: Map of Oye Local Government Area, Ekiti State, Nigeria showing the studied area (Inset: Map of Nigeria showing Ekiti State) 
Aspect of Groundwater Quality Evaluation in Itapa Ekiti...............IGE \& KORODE

Table 1: The statistical summary of water chemistry

\begin{tabular}{lllll}
\hline Parameters & Minimum & Maximum & Mean & Std. dev. \\
\hline $\mathrm{pH}$ & 7.5 & 7.9 & 6.35 & 0.93 \\
Conductivity $(\mu \mathrm{s} / \mathrm{cm})$ & 30 & 900 & 408.67 & 254.8 \\
Temparature $\left({ }^{\circ} \mathrm{C}\right)$ & 27.5 & 29.0 & 28.5 & 28.0 \\
Colour $(\mathrm{Pt} / \mathrm{co}$ unit) & 0 & 61 & 13.23 & 12.6 \\
Turbidity(FTU) & 0 & 12 & 2.36 & 2.92 \\
TDS $(\mathrm{mg} / \mathrm{l})$ & 70 & 500 & 222.3 & 123.3 \\
Total Hardness $(\mathrm{mg} / \mathrm{l})$ & 13 & 188 & 81.2 & 20.4 \\
Total Alkalinity $(\mathrm{mg} / \mathrm{l})$ & 14 & 1424 & 102.5 & 253.1 \\
Chloride $(\mathrm{mg} / \mathrm{l})$ & 0.1 & 90.64 & 39.08 & 28.2 \\
Bicarbonate $(\mathrm{mg} / \mathrm{l})$ & 18 & 180 & 58.30 & 42.6 \\
Sulphate $(\mathrm{mg} / \mathrm{l})$ & 0.85 & 56.1 & 12.70 & 14.5 \\
Nitrate $(\mathrm{mg} / \mathrm{l})$ & 0.14 & 11.27 & 1.0 & 1.9 \\
Calcium $(\mathrm{mg} / \mathrm{l})$ & 2.18 & 51.24 & 23.10 & 12.6 \\
Magnesium $(\mathrm{mg} / \mathrm{l})$ & 1.05 & 15.36 & 6.01 & 4.12 \\
Sodium $(\mathrm{mg} / \mathrm{l})$ & 0.78 & 46.80 & 23.30 & 12.6 \\
Potassium $(\mathrm{mg} / \mathrm{l})$ & 0.41 & 31.98 & 12.50 & 9.8 \\
Iron $(\mathrm{mg} / \mathrm{l})$ & 0 & 0.2 & 0.1 & 0.1 \\
Kelley's ratio & 0.1 & 1.5 & 0.8 & 0.02 \\
Wilcox ratio & 8.8 & 43.7 & 33.1 & 0.3 \\
MR $(\%)$ & 6.3 & 42.0 & 16.5 & 4.7 \\
EB & 0 & 0.4 & 0.2 & 0.1 \\
ID & 1.8 & 1.5 & 0.7 & 0.2 \\
\hline
\end{tabular}

MR: Magnesium Ratio, EB: Electrical Balance, ID: Ionic Difference 


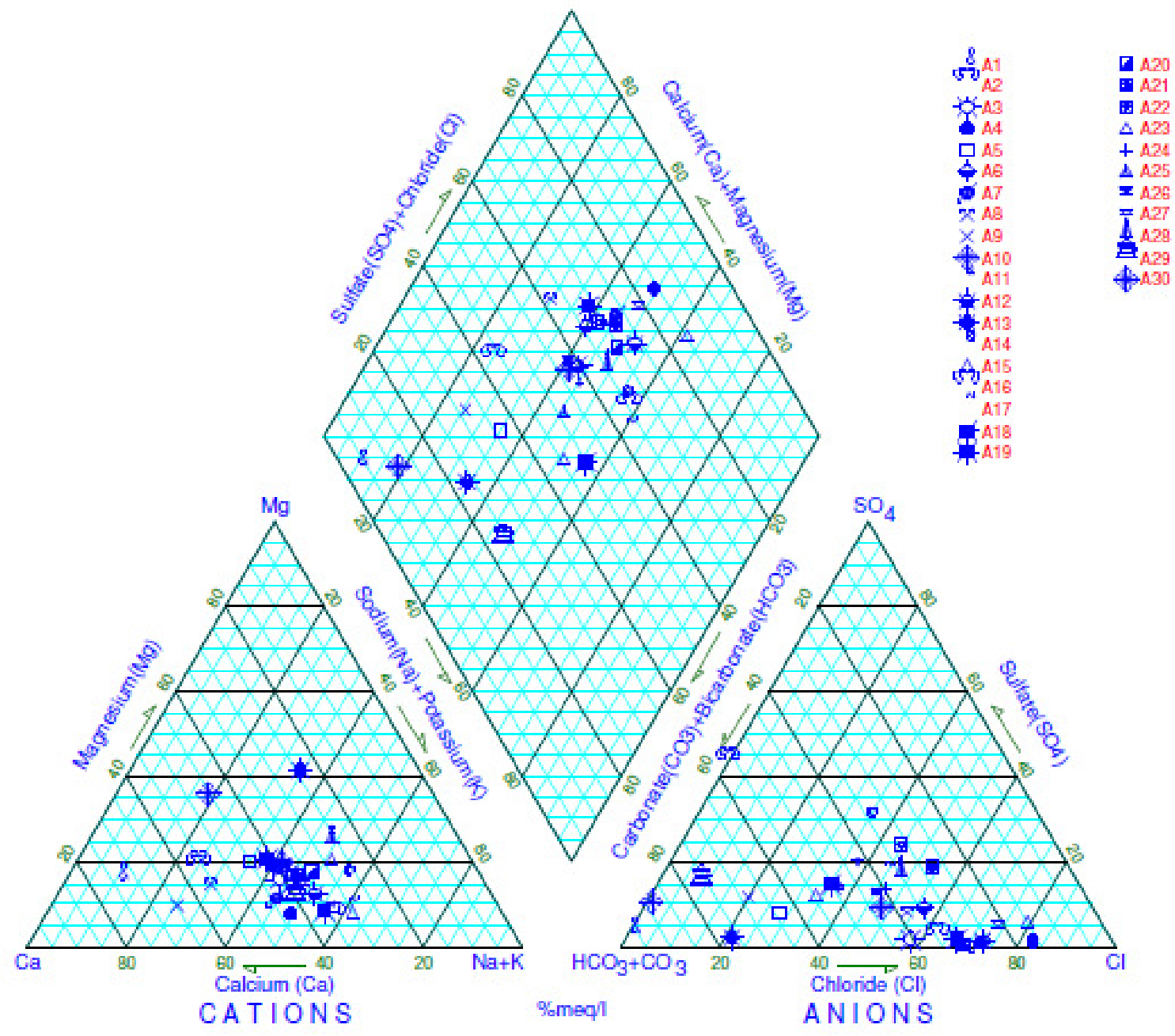

Figure 2: Piper's diagram showing the position of water samples 


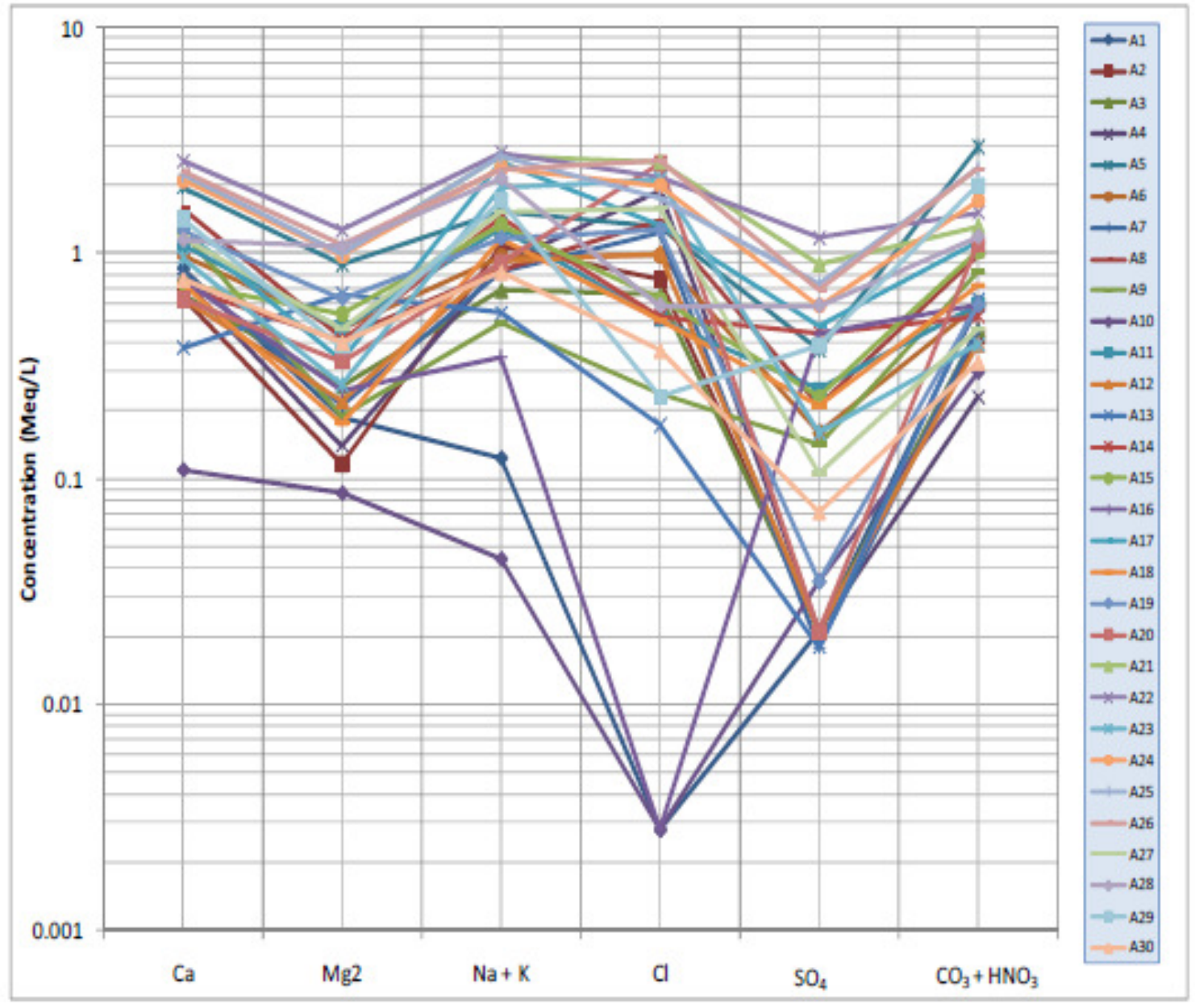

Figure 3: Position of the water samples on the Schoeller's plot 
Ethiopian Journal of Environmental Studies and Management Vol. 8 (Suppl. 2) 2015

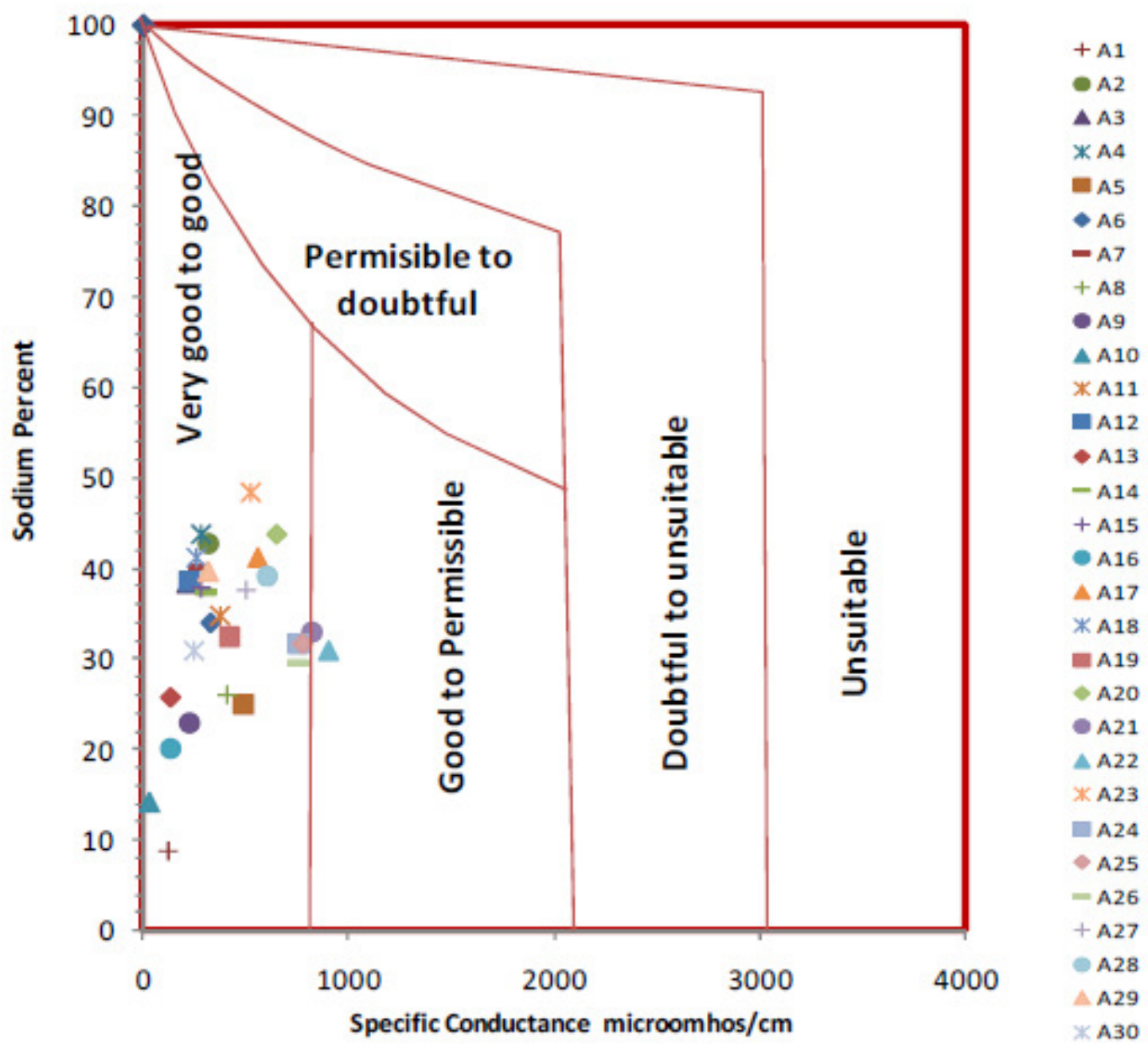

Figure 4: Position of the water samples on the Wilcox plots 
Aspect of Groundwater Quality Evaluation in Itapa Ekiti...............IGE \& KORODE

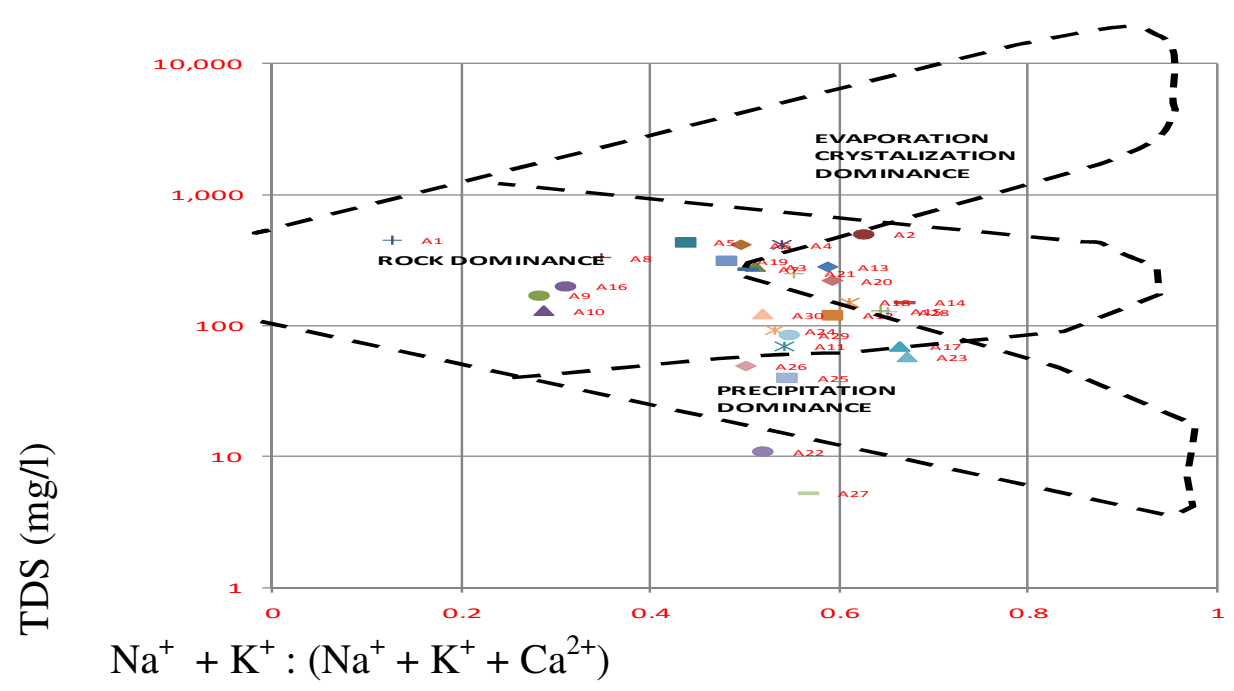

B

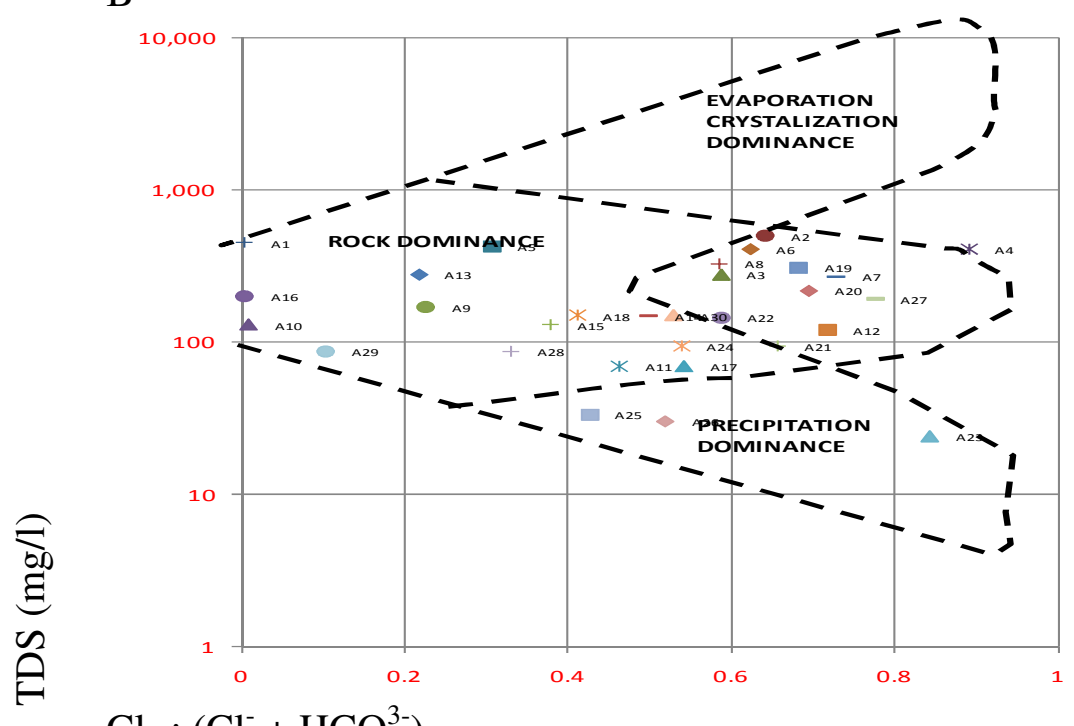

$\mathrm{Cl}-:\left(\mathrm{Cl}^{-}+\mathrm{HCO}^{3-}\right)$

Figure 5: Position of water samples on the Gibbs' diagram (A: Cations; B: Anions) 